\title{
Arahan Pengembangan Kawasan Prigi Kecamatan Watulimo Kabupaten Trenggalek Melalui Konsep Minapolitan
}

\author{
Hesty Ristiani Putri dan Sardjito \\ Jurusan Perencanaan Wilayah dan Kota, Fakultas Teknik Sipil dan Perencanaan, Institut Teknologi Sepuluh Nopember (ITS) \\ Jl. Arief Rahman Hakim, Surabaya 60111 Indonesia \\ e-mail: sardjito24@yahoo.com
}

\begin{abstract}
Abstrak-Kabupaten Trenggalek merupakan salah satu kabupaten yang memiliki Sektor Unggulan berupa Pertanian dengan menyumbang sekitar $37,82 \%$ dari sektor lainnya. Salah satu subsektor unggulan yang ada adalah Perikanan Tangkap yang berada di Kawasan Prigi yang berada di .Kawasan pesisir prigi berpotensi untuk pengembangan perikanan tangkapnya dan dikembangkan melalui konsep Minapolitan agar kawasan tersebut mampu berkembang secara maksimal sebagai poros perekonomian di Kabupaten Trenggalek dengan memaksimalkan potensi perikanan tangkap yang melimpah. Penelitian ini dilakukan melalui empat (4) tahapan analisis. Pertama, Identifikasi faktor pembentuk Minapolitan Kawasan Prigi,Kecamatan Watulimo, Kabupaten Trenggalek dengan teknik analisis Kepustakaan dan Analisis Delphi. Kedua, Menentukan Prioritas Variabel Yang Berpengaruh Dalam Pengembangan Kawasan Prigi Melalui Konsep Minapolitan, Kabupaten Trenggalek dengan (AHP). Ketiga,Menentukan Zona Kawasan Minapolitan di Kawasan Prigi Kecamatan Watulimo Kabupaten Trenggalek dengan menggunakan Analisis Skalogram, Keempat, menggunakan alat analisis deskriptif, yaitu berupa elemen-elemen pembentuk Kawasan minapolitan Prigi, Kecamatan Watulimo, Kabupaten Trenggalek dengan mempertimbangkan potensi kawasan, masalah yang ada di Kawasan dan Arahan pengembangan yang sesuai. Hasil dari penelitian ini adalah berupa jenis arahan berupa peningkatan kegiatan maupun penambahan sarana prasarana pendukung kegiatan minapolitan. Pada Zona Inti, Zona Pengolahan dan Zona Penunjang dimana setiap zona tersebut memiliki arahan program maupun arahan penambahan sarana prasarana dalam mendukungpembentukan Kawasan minapolitan Prigi,Kecamatan Watulimo, Kabupaten Trenggalek.
\end{abstract}

Kata Kunci- Pengembangan Wilayah, Kawasan Minapolitan.

\section{PENDAHULUAN}

$\mathrm{P}$ ENGEMBANGAN wilayah merupakan rangkaian upaya untuk mewujudkan keterpaduan dalam penggunaan berbagai sumber daya, merekatkan dan menyeimbangkan pembangunan nasional dan kesatuan wilayah nasional, meningkatkan keserasian antar kawasan, keterpaduan antar sektor pembangunan melalui proses penataan ruang dalam rangka pencapaian tujuan pembangunan yang berkelanjutan dalam wadah NKRI ( DitJen Penataan Ruang, 2005 ). [1]

Dalam jangka panjangnya pengembangan wilayah mempunyai target untuk pertumbuhan ekonomi dan peningkatan kesejahteraan masyarakat. Cara mencapainya bersandar pada kemampuan SDM dalam memanfaatkan lingkungan sekitar dan daya tampungnya serta kemampuan memanfaatkan instrument yang ada (Ditjen Penataan Ruang, 2005). [2]

Dalam pengembangan wilayah, ada berbagai konsep yang digunakan seperti konsep pengembangan wilayah agropolitan, megapolitan, growth pole, minapolitan, dan lain sebagainya.Konsep-konsep pengembangan wilayah tersebut dapat digolongkan sebagai konsep pengembangan wilayah yang berbasis ekonomi, ekologi, sosial, dan teknologi.Salah satu konsep pengembangan wilayah yang berbasis ekonomi adalah konsep pengembangan Minapolitan (Rustiadi, 2009). [3]

Kabupaten Trenggalek merupakan salah satu kabupaten yang ada di Jawa Timur dengan Sektor Utamanya yaitu Pertanian, dimana sektor pertanian merupakan sektor unggulan dalam menyumbang PDRB terbesar dari Delapan sektor lainnya yaitu sebesar 37,82\%. Dari sektor pertanian terdapat Subsektor yang cukup potensial untuk dikembangkan yaitu Subsektor perikanan. Subsektor perikanan merupakan Subsektor basis dan memiliki daya saing di Kabupaten Trenggalek (RTRW Kabupaten Trenggalek Tahun 20122032). [4]

Pembangunan di bidang kelautan dalam beberapa tahun terakhir menjadi salah satu fokus kajian bagi pemerintah Kabupaten Trenggalek. Sebagaimana yang tercantum dalam Rencana Pembangunan Jangka Menengah Kabupaten Trenggalek tahun 2010-2015. Kabupaten Trenggalek mempunyai luas Zona Eksklusif (ZEE) adalah 35.558 dan panjang pantai selatan Kabupaten Trenggalek sepanjang 96 $\mathrm{km}$ yang sebagian besar pantainya berbentuk teluk dengan salah satunya yaitu Kawasan Prigi yang merupakan kawasan pesisir terbesar (Kabupaten Trenggalek Dalam Angka 2014). Kawasan Prigi yang terletak di merupakan kecamatan dengan penghasil perikanan tangkap terbesar di Kabupaten Trenggalek.Terdapat tiga (3) lokasi di Kabupaten Trenggalek yang mempiliki potensi hasil perikanan tangkap yaitu , Munjungan dan Panggul. Diantara ketiga lokasi tersebut (Prigi) merupakan kawasan yang memiliki potensi pengembangan hasil tangkapan terbesar, selain itu kondisi alam juga mempengaruhi jumlah dari hasil tangkapan ikan laut di ketiga lokasi tersebut, yaitu (prigi) menjadi pusat 


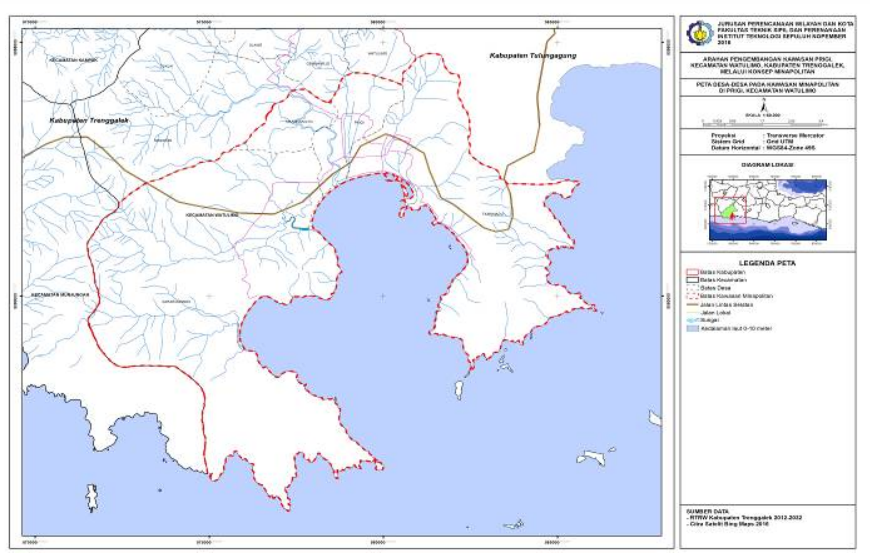

Tahap 1 : Peta desa-desa yang mempunyai potensi untuk dikembangkan Minapolitan di Prigi
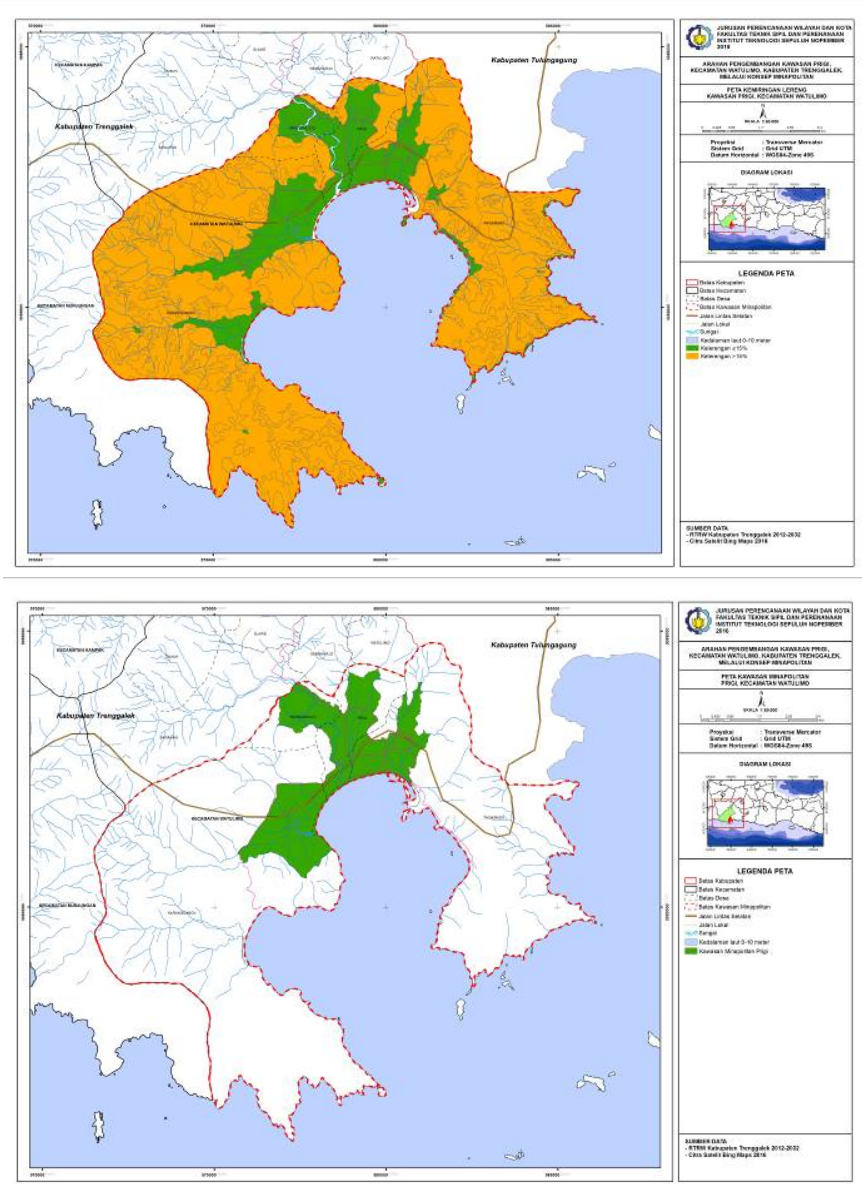

Tahap 2 : Peta Kelerengan lahan dan Peta Kawasan potensial pengembangan Minapolitan di Prigi

pemasaran dari ketiga lokasi tersebut, sehingga berpotensi untuk dikembangkan menjadi kawasan Minapolitan tangkap.[5]

Dilihat dari produksi ikan yang meningkat sampai tahun 2013 seharusnya penyerapan tenaga kerja sebagai nelayan juga bertambah, berkurangnya jumlah nelayan diakibatkan karena adanya permasalahan yang dihadapi nelayan seperti rendahnya penguasaan teknologi,keterampilan masyarakat pesisir, rendahnya akses terhadap permodalan, keterbatasan jenis

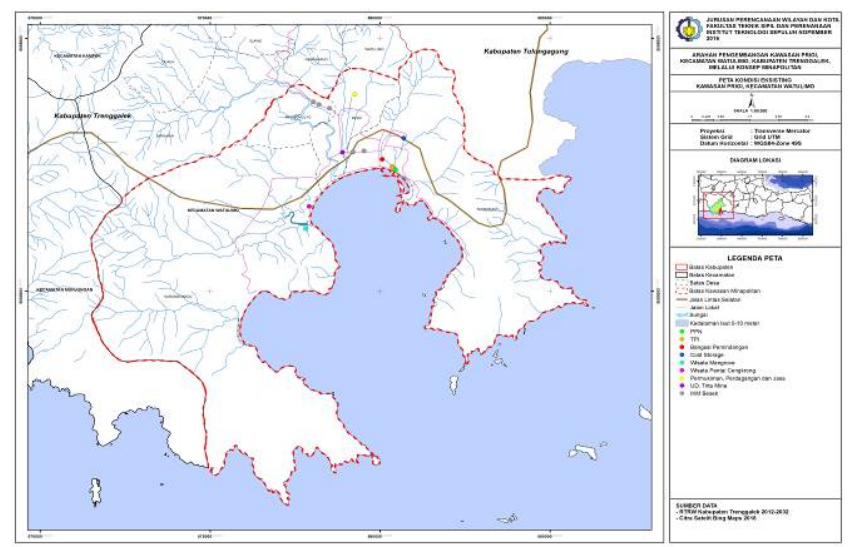

Tahap 3 : Peta Kondisi Eksisting Kawasan Prigi

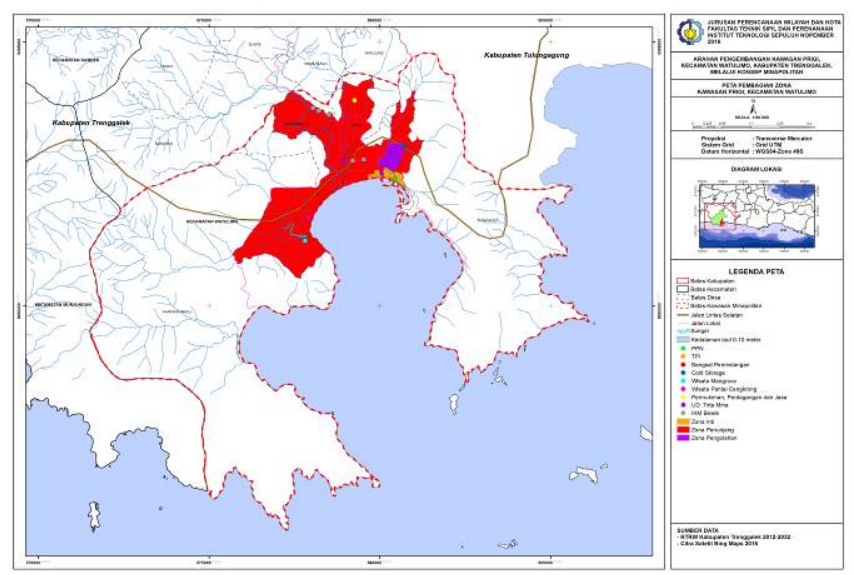

Tahap 4: Peta Pembagian Zonasi Kawasan minapolitan di Prigi, Kecamatan Watulimo, Kabupaten Trenggalek

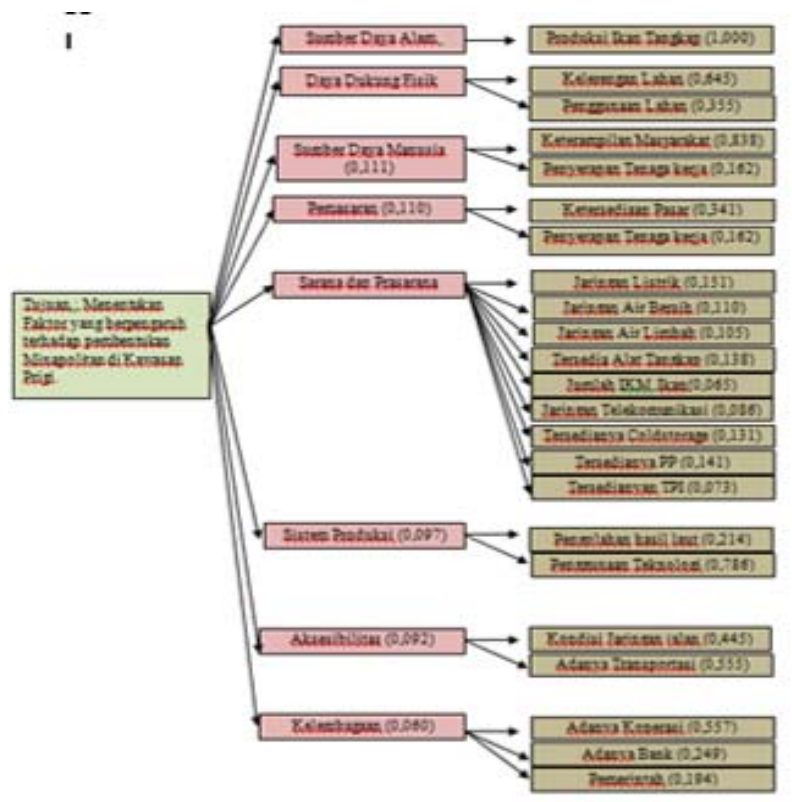

Sumber: Hasil Analisis, 2016

produk olahan ikan yang hanya di pasarkan dalam bentuk mentah, sebagian besar hasil tangkapan laut langsung dijual ke pedagang maupun ke pengepul dalam keadaan segar tanpa 
pengolahan untuk mendapatkan added valuenya, sebagian 


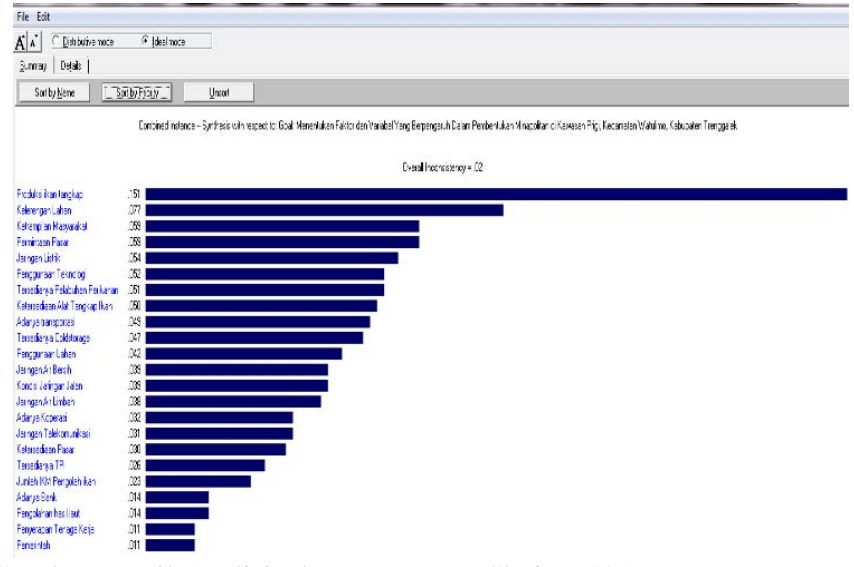

Sumber: Hasil Analisis dengan Expert Choice, 2016

besar industri rumah tangga seperti pemindangan masih bersifat tradisional sehingga kegiatan pengolahan bersifat sederhana dan terbatas baik secara kualitas (Antara News Jawa Timur, 2015), sarana dan prasarana pendukung industri perikanan yang kurang,semakin berkurangnya sumber daya laut di wilayah sekitar pantai merupakan kondisi yang kerap kali menyebabkan kehidupan sehari-hari nelayan miskin makin terpuruk.[6]

Dengan adanya permasalah yang terdapat di Kawasan Prigi seperti tersebut, maka dengan adanya penyusunan kawasan yang lebih sinergi akan semakin memberikan peluang untuk dikembangkan dan mampu meraih pasar yang lebih baik, peningkatan produksi dengan kualitas dan kuantitas yang baik serta memicu pertumbuhan ekonomi lokal berbasis perikanan tangkap. Oleh karena itu diperlukan arahan yang sesuai untuk pengembangan Kawasan Prigi melalui konsep Minapolitan.[7]

\section{METODE PENELITIAN}

\section{A. Jenis dan Pendekatan Penelitian}

Pendekatan yang digunakan dalam penelitian ini adalah pendekatan rasionalistik. [8] Jenis penelitian dalam penelitian ini adalah deskriptif kualitatif.

\section{B. Variabel Penelitian}

Variabel penelitian yang digunakan untuk mengidentifikasi faktor dan variabel yang berpengaruh terhadap pembentukan Minapolitan di Kawasan Prigi antara lain 1)Produksi ikan tangkap sebagai bahan baku, (2)Keterampilan masyarakat pesisir, (3)Penyerapan Tenaga Kerja, (4)Ketersediaan Jaringan Listrik, (5)Ketersediaan Jaringan Air Bersih, (6)Ketersediaan Pembuangan limbah, (7)Ketersediaan Alat Tangkap Ikan, (8)Jumlah IKM pengolahan ikan, (9)Ketersediaan Jaringan Telekomunikasi, (10)Adanya Coldstorage, (11)Tersedianya Pelabuhan perikanan, (12)Ketersediaan Tempat Pelelangan Ikan (TPI), (13)Kondisi jaringan jalan, (14)Tersedianya Koperasi, (15)Lembaga Pemerintah, (16)Ketersediaan Bank , (17) Ketersediaan pasar, (18)Permintaan pasar, (19)Pengolahan hasil laut (untuk added value), (20)Penggunaan Teknologi, (21)Kelerengan Lahan, (22)Penggunaan Lahan, (23) Kelompok Nelayan.
C. Mengidentifikasi faktor dan variabel pembentuk

Minapolitan di Kawasan Prigi, Kecamatan Watulimo, Kabupaten Trenggalek.

Dalam menentukan faktor dan variabel pembentuk Minapolitan di Kawasan Prigi,Kecamatan Watulimo, Kabupaten Trenggalek yaitu dengan menggunakan teknik analisis tinjauan pustaka dan Delphi.

Analisis Kepustakaan menurut Nazir (1998 : 112) merupakan langkah yang penting dimana setelah seorang peneliti menetapkan topik penelitian, langkah selanjutnya adalah melakukan kajian yang berkaitan dengan teori yang berkaitan dengan topik penelitian. Dalam pencarian teori, peneliti akan mengumpulkan informasi sebanyak-banyaknya dari kepustakaan yang berhubungan. Sumber-sumber kepustakaan dapat diperoleh dari: buku, jurnal, majalah, hasilhasil penelitian (tesis dan disertasi), dan sumber-sumber lainnya yang sesuai (internet, koran dll). Dan berikut merupakan diagram analisa Delphi.

D. Menentukan Zonasi minapolitan di Kawasan Prigi ,Kecamatan Watulimo ,Kabupaten Trenggalek.

Analisis Skalogram digunakan untuk menentukan Kawasan Minapolitan di Prigi dengan tahapan:

1. Tahap pertama, diindentifikasi terkait kelengkapan fasilitas perikanan yang sudah dimiliki, dengan skalogram dihasilkan beberapa desa yang masuk dalam kategori minapolitan karena memiliki kelengkapan fasilitas yang cukup mendukung.

2. Tahap kedua, yaitu menganalisis bagian wilayah yang sesuai untuk dikembangkan minapolitan dengan menggunakan peta kelerengan untuk mengetahui kawasan yang sesuai untu dibangun sebagai minapolitan.

3. Tahap ketiga adalah pembuatan peta eksisting, hal ini dilakukan untuk mengetahui letak dari Sarana dan Prasarana pendukung perikanan yang ada di Kawasan Prigi.

4. Tahap keempat, yaitu pembuatan peta zonasi minapolitan dengan menggunakan batasan dari semua hasil analisis yang telah dilakukan dari tahap pertama sampai ketiga.

E. Menentukan Prioritas Variabel Yang Berpengaruh Dalam Pengembangan Kawasan Prigi Melaui Konsep Minapolitan , Kabupaten Trenggalek

Dalam menentukan variabel-variabel prioritas apa saja yang berpengaruh terhadap pengembangan kawasan prigi dengan konsep Minapolitan teknik analisis yang digunakan yaitu Analytical Hierarchy Process (AHP), dimana dari proses analisis kajian pustaka dan analisis delphi akan dikeluarkan faktor-faktor pembentuk minapolitan di kawasan Prigi.

Perumusan Arahan Pengembangan Kawasan Prigi, Kecamatan Watulimo, Kabupaten Trenggalek Melalui Konsep Minapolitan

Dalam menentukan arahan pengembangan pada Kawasan Prigi menjadi minapolitan berdasarkan variabel-variabel yang diprioritaskan, yang kemudian menggunakan analisis deskriptif dalam perumusan arahannya, yang dikomparasikan 
antara potensi kawasan, masalah pada kawasan dan arahan yang sesuai untuk pengembangan.

\section{HASIL DAN DISKUSI}

A. Mengidentifikasi faktor dan variabel pembentuk Minapolitan di Kawasan Prigi, Kecamatan Watulimo, Kabupaten Trenggalek.

Berdasarkan hasil tinjauan pustaka didapatkan faktor dan variabel yang berpengaruh terhadap pembentukan minapolitan di Kawasan Prigi, yaitu :

1. Sumber Daya Alam (SDA)

2. Sumber Daya Manusia (SDM)

3. Sarana dan Prasarana Pendukung Perikanan

4. Aksesibilitas

5. Kelembagaan

6. Pemasaran

7. Sistem Produksi

8. Daya Dukung Fisik

Berikut merupakan variabel-variabel pembentuk Minapolitan di Kawasan Prigi, antara lain:

1) Produksi ikan tangkap sebagai bahan baku

2) Keterampilan masyarakat pesisir

3) Penyerapan Tenaga Kerja

4) Ketersediaan Jaringan Listrik

5) Ketersediaan Jaringan Air Bersih

6) Ketersediaan Pembuangan limbah

7) Ketersediaan Alat Tangkap Ikan

8) Jumlah IKM pengolahan ikan

9) Ketersediaan Jaringan Telekomunikasi

10) Adanya Coldstorage

11) Tersedianya Pelabuhan perikanan

12) Ketersediaan Tempat Pelelangan Ikan (TPI)

13) Kondisi jaringan jalan

14) Tersedianya Koperasi

15) Lembaga Pemerintah

16) Ketersediaan Bank

17) Ketersediaan pasar

18) Permintaan pasar

19) Pengolahan hasil laut (untuk added value)

20) Penggunaan Teknologi

21) Kelerengan Lahan

22) Penggunaan Lahan

B. Menentukan Zonasi minapolitan di Kawasan Prigi ,Kecamatan Watulimo ,Kabupaten Trenggalek

Dalam menentukan zonasi kawasan minanpolitan menggunakan analisis Skalogram untuk mengidentifikasi desa-desa yang memiliki potensi untuk dikembangkan menjadi kawasan minapolitan seperti tahapan-tahapan pada bab metode penelitian yang sudah dijelaskan. Berikut merupakan Output berupa peta dalam menentukan Zonasi Kawasan Minapolitan di Prigi dapat dilihat pada Gambar Tahap 1- Tahap 4.
C. Menentukan Prioritas Variabel Yang Berpengaruh Dalam Pengembangan Kawasan Prigi Melaui Konsep Minapolitan , Kabupaten Trenggalek

Berikut merupakan hasil dar analisis dengan menggunakan Analisis AHP (Analytichal Hierarchy Process) dalam penentuan variabel prioritas dalam pembentukan Minapolitan di Kawasan Prigi dapat dilihat pada diagram hasil analisis.

Berikut merupakan hasil penghitungan bobot keseluruhan variabel dengan menggunakan alat analisis Expert Choice,11, didapatkan hasil seperti pada gambar dibawah ini dapat dilihat pada Gambar Hasil Analisis dengan Expert Choice.

Arahan Pengembangan Kawasan Prigi, Kecamatan Watulimo, Kabupaten Trenggalek Melalui Konsep Minapolitan

Berikut merupakan rumusan arahan pengembangan Kawasan Prigi Kecamatan Watulimo Kabupaten Trenggalek Melalui Konsep Minapolitan yang dibagi Tiap Sentra, dimana penjabaran dari variabel-variabel pembentuk minapolitan dan juga penambahan beberapa sarana prasarana pendukung minapolitan menurut Teori maupun sumber literature lainnya pada sasaran dua (2) yang menjelaskan bahwa di sebuah Kawasan minapolitan tidak hanya arahan penambahan program saja yang dibutuhkan melainkan juga dukungan sarana prasarananya juga harus mendukung.

Arahan pada Zona Inti kawasan Prigi menjadi Kawasan Minapolitan yaitu:

1. Mengaktifkan kembali gerakan konservasi alam guna untuk untuk tetap menjaga kelestariannya

2. Melakukan program konservasi tanah untuk mengetahui kemampuan tanah untuk pengembangan kawasan minapolitan

3. Melakukan penyuluhan dan pendampingan masyarakat

4. Pemerataan jaringan listrik pada Zona-zona kawasan minapolitan

5. Peningkatan kinerja Pelabuhan perikanan agar semakin efektif

6. Penambahan alat tangkap ikan modern untuk nelayan tradisional

7. Penambahan sarana transportasi sebagai sarana akomodasi dalam penjualanhasil laut

8. Perbaikan akses jalan ,guna mempermudah aksesibilitas aktivitas perekonomian

9. Pembangunan dan penambahan jaringan limbah guna mendukung kegiatan pengolahan di Kawasan Minapolitan

10. Pengaktifan kembali TPI dengan melakukan kegiatan pelelangan ikan setelah ikan mendarat

11. Pemerintah melakukan promosi guna menarik investor untuk menanamkan modal di Kawasan Prigi agar jauh lebih berkembang dan lengkap secara sarana dan prasarananya

Arahan pada Zona Pengolahan kawasan Prigi menjadi Kawasan Minapolitan yaitu:

1. Melakukan program konservasi tanah untuk mengetahui kemampuan tanah untuk pengembangan kawasan minapolitan 
2. Melakukan penyuluhan dan pendampingan masyarakat untuk meningkatkan keterampilan

3. Memfasilitasi para pengusaha kecil dengan cara mencarikan pengusaha maupun investor agar dapat diajak kerjasama

4. Pemerataan jaringan listrik pada Zona-zona kawasan minapolitan

5. Penambahan dukungan teknologi modern untuk menghasilkan added value

6. Penambahan sarana transportasi sebagai sarana akomodasi dalam penjualanhasil laut

7. Penambahan coldstorage untuk meningkatkan produksi ikan segar berkualitas siap ekspor

8. Perbaikan akses jalan ,guna mempermudah aksesibilitas aktivitas perekonomian

9. Pembangunan dan penambahan jaringan limbah guna mendukung kegiatan pengolahan di Kawasan Minapolitan

10. Melakukan penyuluhan dan bimbingan terhadap IKM pengolaha hasil laut agar mampu lebih kreatif dalam mengolah produknya

11. Program pendampingan usaha untuk masyarakat dalam pengolahan hasil laut yang lebih variatif

12. Pemerintah melakukan promosi guna menarik investor untuk menanamkan modal di Kawasan Prigi agar jauh lebih berkembang dan lengkap secara sarana dan prasarananya

Arahan pada Zona Penunjang kawasan Prigi menjadi Kawasan Minapolitan yaitu:

1. Melakukan program konservasi tanah untuk mengetahui kemampuan tanah untuk pengembangan kawasan minapolitan

2. Pemerataan jaringan listrik pada Zona-zona kawasan minapolitan

3. Penambahan sarana transportasi sebagai sarana akomodasi dalam penjualanhasil laut

4. Pengoptimalan penggunaan lahan dengan cara pengalihan fungsi jenis kegiatan yang dilakukan, seperti dengan pembangunan gudang mesin-mesin kapal yang belum tersedia di kawasan tersebut

5. Pengembangan embung jaringan air baku dan pemerataan saluran PDAM untuk air bersih

6. Perbaikan akses jalan ,guna mempermudah aksesibilitas aktivitas perekonomian

7. Penyuluhan terkait bagaimana menyusun rencana, program dan kegiatan usaha agar koperasi mampu mencapai program yang diinginkan

8. Penambahan fasilitas telecenter yang berfungsi sebagai pusat informasi berbasis internet yang mampu memberdayakan masyarakat dengan kemudahan akses terhadap informasi

9. Penambahan fasilitas berupa pembangunan pasar khusus sebagai tempat penjualan alat penunjang perikanan tangkap

10. Program kerjasama dengan pihak bank untuk membuat Sistem KUR (Kredit Usaha Rakyat)
11. Melakukan program pembekalan kepada masyarakat agar mereka mampu berkembang dan mengembangkan potensi alam yang mereka miliki

12. Pemerintah melakukan promosi guna menarik investor untuk menanamkan modal di Kawasan Prigi agar jauh lebih berkembang dan lengkap secara sarana dan prasarananya

Selain itu, adapun sarana prasarana yang perlu ditambahkan dalam pengembangan Kawasan Prigi menajdi Kawasan Minapolitan adalah sebagai berikut:

1) Pada Zona Inti :

Perlu perbaikan akses jalan penghubung antar desa-kota karena kondisinya yang kurang begitu baik, berupa jalan pegunungan yang sebagian rusak.

Penambahan Gudang Penyimpanan mesin usaha tangkap ikan.

\section{2) Pada Zona Pengolahan:}

Penambahan tempat pengolahan ikan modern seperti pabrik tepung ikan,sarden,pengolahan siap saji dalam kemasan

Pembuatan STA (Sub Terminal Agribisnis) sebagai sarana yang mampu mengelola pasokan hasil perikanan yang memenuhi syarat kualitas, kuantitas, kontinuitas, dan harga produk hasil perikanan yang pantas diterima baik oleh nelayan, pengusaha kecil maupun konsumen.

Pembuatan saluran pembuangan limbah industri hasil olahan.

3) Pada Zona Penunjang:

a. Pembuatan pasar khusus sebagai tempat penjualan penunjang produksi perikanan,seperti besek

b. Pembuatan balai pendidikan dan pelatihan kerja nelayan dan pengusaha kecil.

c. Penambahan jasa transportasi (rental mobil pengangkut ikan) pengangkutan barang produksi berupa ikan tangkap untuk dipasarkan keluar kota/daerah

d. Penambahan Layanan Informasi Agribisnis perikanan tangkap, yaitu berupa pembangunan telecenter.

\section{KESIMPULAN DAN REKOMENDASI}

Hasil dari penelitian ini adalah berupa jenis arahan berupa peningkatan kegiatan maupun sarana prasarana pendukung kegiatan minapolitan. Adapun pembagian zona terdapat tiga (3) yaitu Zona Inti, Zona Pengolahan dan Zona Penunjang dimana setiap dari zona tersebut memiliki arahan program maupun arahan penambahan sarana prasarana dalam mendukung minapolitan.

Adapun beberapa rekomendasi yang dapat diberikan dalam penelitian ini antara lain:

1. Diperlukan study lanjutan terkait fokusan dari jenis kegiatan pengolahan komoditas unggulan ikan tangkap di Kawasan Prigi agar nantinya mampu memberikan nilai tambah bagi kawasan tersebut.

2. Penelitian ini dapat menjadi bahan pertimbangan bagi pemerintah dalam mengembangkan wilayah Prigi yang berpotensi menjadi Kawasan Minapolitan. 


\section{DAFTAR PUSTAKA}

[1] Dinas Kelautan dan Perikanan Provinsi Jawa Timur. 2015. Pedoman Umum Pengembangan Kawasan Agropolitan dan Minapolitan Provinsi Jawa Timur 2015.

[2] Ikhsan, Barkey, R. A., \& Arief, A. (2012). Strategi Pengembangan Kawasan Minapolitan Rumput Laut di Kecamatan Pajukukang Kabupaten Bantaeng. Makassar: Program Studi Perencanaan Pengembangan Wilayah - Universitas Hasanuddin.

[3] PeraturanMenteri Kelautan Dan Perikanan Republik Indonesia Nomor: Per.12/Men/2010 TentangMinapolitan.

[4] Peraturan Menteri Kelautan Dan Perikanan Republik Indonesia Nomor: Per.18/Men/2012TentangPedoman Penyusunan Rencana Induk PengembanganKawasan Minapolitan.

[5] Peraturan Daerah Kabupaten Trenggalek Nomor: 15 Tahun 2012, Tentang Rencana Tata Ruang WilayahKabupaten Trenggalek Tahun $2012-2032$

[6] Pratomo, H. (2003). Pemberdayaan Nelayan Melalui Pengolahan Ikan Pasca Produksi. Jurnal Inoteks, Vol. 5, No.1, 51-60.

[7] Sekretariat Jenderal Kelautan dan Perikanan. 2013. Pengembangan Kawasan Minapolitan.

[8] Wiadnya, D. G. (2011). Konsep Perencanaan Minapolitan Dalam Pengembangan Wilayah. Malang: Fakultas Perikanan \& Ilmu Kelautan (FPIK), Universitas Brawijaya (UB). 